Mike Raco and Federico Savini eds (2019) Planning and Knowledge - how new forms of technocracy are shaping contemporary cities [ISBN 978-1-4473-4524-4] Bristol: Policy Press ch.2, pp.19-30

Planning, Knowledge and Technocracy in Historical Perspective

Michael Hebbert

\title{
Introduction
}

Fifty years ago William Armytage opened his history of the rise of technocracy with the Homeric image of Laocoön, the priest of Apollo who tried to convince his fellow-citizens to reject the wooden horse left by the Greeks outside the walls of Troy. Just as he was making his case two serpents suddenly emerged from the sea and crushed him to death (fig 2.1) Armytage comments: 'similarly latent, but aggressive, social forces emerge from below the "social horizon" to confound historians' (1965 vii).

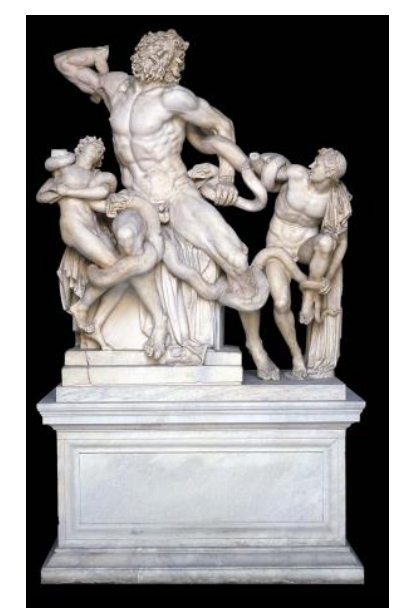

Figure 2.1 Laocöon and his sons attacked by sea-serpents (Vatican Museum cat. 1059) 
Setting aside for the moment the question whether they're an apt metaphor for technocracy, those serpents swimming below the surface certainly do match the case of neoliberalism. Kim Phillips-Fein (2009) has shown how neo-conservative ideologues were secretively bank-rolled for decades by American businessmen and wealthy pro-marketeers. Nancy Maclean (2017) has called the radical right agenda a 'stealth plan'. The programme for dismantling the welfare state took shape below the social horizon until the 1980s, since when its offensive has been abrupt, implacable and all-pervasive. Neo-conservatism has shifted the fundamentals of social thought, enabling particularist knowledge to undermine the concepts of collective welfare and public interest. It has hollowed out the institutional apparatus of the nation-state and emptied the distinction between public and private sectors. It has caused local governments to abandon time-honoured methods of accountability and embrace quasi-corporate management structures and remuneration pyramids. The United Kingdom's local government map has been repeatedly redrawn, almost always in the direction of fewer, larger units devoid of municipal identity. The extent of its success could be measured by the extensive termination of local public services in the aftermath of the 2008 banking crash: a process best described, as Tom Crewe notes, not in terms of 'cuts' or 'austerity' but as the deliberate destruction of an entire social infrastructure (2016 7).

The neo-liberal era has brought a fresh cast of actors onto the stage with their own discourses, metrics, analytical techniques, and modes of communication: examples discussed in this book include signature architects (Ponzini), brokers (Aalbers), deal-makers (Tusan-Kok), development engineers (Metzger and Zakhour), housing spreadsheet 
consultants (Layard), fixers (Mössner and Gomes), futurists (Webber), journalists (Livingstone), lobbyists (Hirvola), participation consultants (Brownill), scrutineers (Parker \& Street), smart city wonks (Kitchen). Some of their knowledges arise directly from neo-liberal economic relations, others reflect wider technical shifts in ITC, the ubiquity of smartphones, the integrative power of GIS, the locational pin-pointing of GPS. Consequently the nature of technocracy - the legitimation of power by expertise - has changed.

Our book offers an original analysis of the new forms of technocracy and the ways in which they are reshaping contemporary cities. Who are these actors that have been empowered by neo-liberalism ? How do they think ? What do they do ? And what are the consequences for the world around us ? These are the questions addressed by fellow-authors. The task for the present chapter is different. To make sense of the new technocracy we must understand the old. The following pages put the present critique of expert knowledge into historical perspective, looking back to the interplay of planning and technocracy in the century of two World Wars, the New Deal, the Welfare State and the Modern Project.

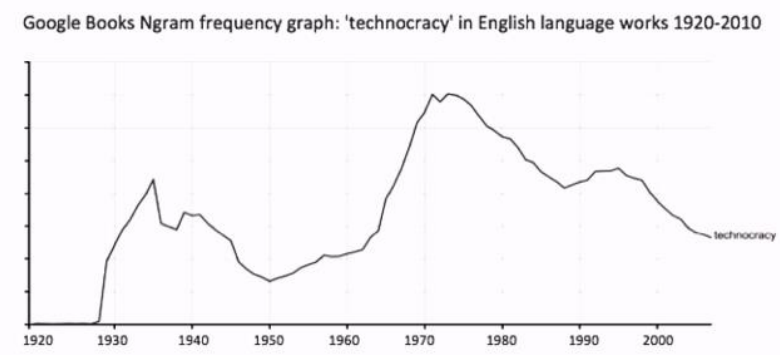

Figure 2.2 'Technocracy' word frequency in English books 1920-2015

Source: https://books.google.com/ngrams 


\section{The First Wave}

Let's begin with our keyword. The term 'technocracy' entered the English language a century ago and a frequency graph of its usage (Fig.2.2) displays two peaks forty years apart. Closer inspection reveals significant semantic shifts between the two.

As the Ngram shows, 'technocracy' first appeared early in the last century and enjoyed a spurt of popularity in the mid-twenties. The word was coined by the prolific English-born, California-based engineer William Henry Smyth (1855-1940) and used in various papers he published from 1919 onwards (Akin 1977, Fischer 1990). Under the guise of a whacky characterisation of the Clam-Digger descendants of Irascible Strong and his wife Trixie Cunning (Fig.3) Smyth offered a serious critique of the inappropriateness of the psychological mentality of primitive hunter-gatherers to the problems of machine-age society :-

'a nation (and above all an industrial democracy) should have a definite purpose, An army is officered by military specialists; a business organization is officered by business specialists; and industrial democracy - a democracy of technical industries - should be officered by technical specialists - should be in form and in fact a purposive Technocracy' (1926 284) 
$C O N C E R N I N G$

\section{R A S C I B L E $\quad S$ T R O N G}

A N D TRIXI E-C U N N I N G,

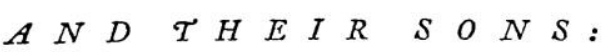

Cunning-Strong, Skilful-Strong,

Simple-Strong, Tricksy-Cunning,

and their descendants:

killer Chesty, hocus-pocus Smoothy, rough cusswordy Knapper, acquisitive Fatty,

and the preoccupied Diggers;

All of the busy Clam Digger Tribe,

$$
\begin{gathered}
A N D \\
\text { Their descendants. }
\end{gathered}
$$

WITH SKETCHES BY THE AUTHOR,

W I L I A M H. S M Y TH.

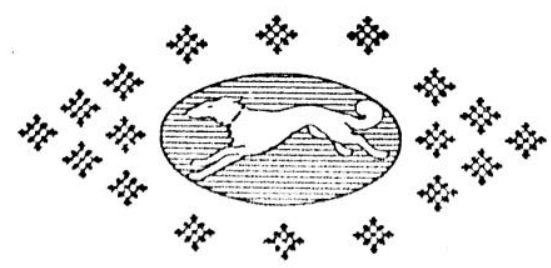

ALFRED A. KNOPF, NEW YORK:

$M C M \quad X \times 1$.

Figure 2.3 Smyth (1926) title page, from Siegel \& Strain (2011) p.29 
Smyth's useful term was taken up by Howard Scott, a floor polish manufacturer, political entrepreneur and self-styled engineer active in progressive Greenwich Village discussion circles in the 1920s. In 1929 Scott licensed the brand name - Technocracy Inc. - for a movement that briefly captured the public mood in the aftermath of the Wall Street Crash. Its platform was the application of scientific expertise to collective decision-making, and replacement of the monetary dollar with energy certificates, linking economic value to the environmental resource base. In the technocratic utopia both ideological politics and the vagaries of the market would be replaced by the engineer's dispassionate quest for efficiency. The word's spurt of popularity can be seen in the Ngram and so can its precipitous decline after Scott was discredited in 1933 for lack of formal qualification. Though the organised movement continued in existence until his death in 1970 it was a mere shell without political significance.

Armytage's Laocoön metaphor points to the powerful forces that swim below the surface in the history of ideas. Howard Scott emerged from the discussion circles around Thorstein Veblen at the New School for Social Research in New York City. His Technocracy platform blended elements of the Taylorism promoted by the Taylor Institute (followers of Frederic Winslow Taylor) and the Fordism preached by followers of Henry Ford, with the hugely influential Utopianism of Edward Bellamy's Looking Backwards. Armytage contextualises it both historically and comparatively, tracing its antecedents through nineteenth century Utilitarianism and Positivism back to the origins of modern applied science and revealing the multiple connections between American technocratic thinking and its European, Russian and Japanese 
counterparts. The doctrine of scientific management had few more enthusiastic promoters than the Bolshevik Gleb Maksimilianovich Krzhizhanovsky - in Armytage's words 'the most portentous technocrat of them all' (1965 219) - whom Lenin appointed to chair both the Soviet State Planning Commission GOSPLAN and the electrification programme GOELRO. Soviet Five Year Plans in their turn influenced the American New Deal initiatives, especially its most ambitious spatial experiment, the Tennessee Valley Authority (TVA).

Walter Creese notes the close parallels between TVA's gestation and the Technocracy movement, both drawing utopian inspiration from the transformative potential of electrification (2003 70). However the launch of TVA in 1933 coincided with the collapse of Scott's movement, and the emergence of a different terminology - 'planning' rather than 'technocracy'. In the title of Julian Huxley's widely-read wartime account TVA was the supreme Adventure in Planning, a practical demonstration 'that there is no antithesis between democracy and planning, and that planning can not only be reconciled with individual freedom and opportunity, but can be used to enhance and enlarge them' (1943 135).

As Howard Scott's stock declined, technocracy's credit transferred to the wider quest for planning, an active participle with humanistic resonance, as applicable to individuals and social organisations, as to business corporations and governments at every scale (Doob 1940). In the United Kingdom Julian Huxley and his brother Aldous popularised the perception of planning as a non-partisan Third Way out of the Depression through the medium of a think-tank, Political \& Economic Planning - PEP - launched in 1931 with Sir Basil Blackett (Bank of 
England), I M Sieff (M\&S) and Lionel Elmhirst (Dartington Hall). The following year President F.D. Roosevelt launched American's New Deal with a leading exponent of planning, Rexford Tugwell, as one of his closest advisers. When Tugwell left the Federal Administration in 1936 he became Chairman of the New York Planning Commission and subsequently Governor of Puerto Rico, in each context applying a planning methodology of data collection, collective goal-setting, and medium-term strategy. In the extensive literature on social reconstruction of the 1940s it was axiomatic that the future division of labour should include an expert-based collective planning system as a third sector, breaking the traditional duopoly of politics and the market. Routledge \& Kegan Paul published a prominent series on the topic, the International Library of Sociology and Social Reconstruction, edited by Karl Mannheim, with the logo 'tree of science, tree of life' (Fig. 2.4). It included E.A. Gutkind's two volumes on Creative Demobilisation (1943) and his own posthumous Freedom Power and Democratic Planning (1951).

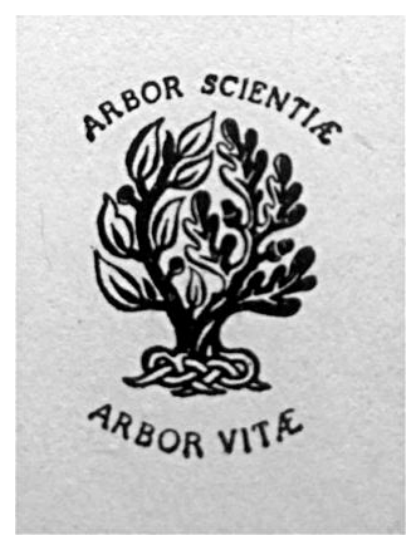

Figure 2.4 Symbol of Mannheim's International Library of Sociology \& Social Reconstruction 
While Karl Mannheim's preached the doctrine of democratic planning from his new academic home at the London School of Economics his sceptical colleagues and fellow-emigrés Karl Popper and Friedrich Hayek laid the philosophical basis for its antithesis. Popper's Poverty of Historicism (1957) argued the impossibility of planning. He challenged both the epistemological basis of knowledge for collective action and the moral claim of its historical inevitability. 'You cannot centralise within a planning authority the knowledge relevant for such tasks as the satisfaction of personal needs or the utilization of specialist skill and ability' (1957 p.64). Given the fundamental flaws in the knowledge base for holistic planning the only rational basis for action, so Popper argued, was piecemeal incrementalism. Hayek's earlier book The Road to Serfdom (1944) offered a more polemical critique of the efforts of the planning movement to build a welfare state upon the basis of impartial expertise. He prophesied that specialists and single-issue reformers were being drawn by the promise that their agenda would be advanced in a future planned society: implementation of this utopia was bound to disappoint since it could only bring out the concealed conflict between their aims. Disappointment would trigger further self-defeating attempts to centralise control. So democratic socialism was a slippery slope, leading inevitably to authoritarian denial of freedoms. Hayek's sophisticated advocacy of private property rights as the only guarantor of freedom appealed to the nascent American neo-conservative movement, causing the business activist Harold Luhnow to arrange for him to be appointed by the University of Chicago with a ten year subsidy on his salary (Phillips-Fein 2009).

Hayek's time would come, but for the first three postwar decades - les 
trentes glorieuses - the advocacy of the planning movement shaped the institutional design of the postwar world: at the local level, in systems of land use planning such as the UK's celebrated Town \& Country Planning Act of 1947; in the seminal regional planning mechanisms of the French state, whose designer Paul Delouvrier deliberately excluded the possibility of 'sterile' political participation (Valade 2008 136); in macroeceonomic mechanisms of five year plans, devised and implemented by the technical élites of the grands écoles, that drove the growth of the French economy over the three decades of les trentes glorieuses; and internationally, in the multiple expert-led agencies established under the auspices of the UN, or the Commission established by Jean Monnet as the foundation-stone of European integration. Faith in rationality lay at the heart of the Modern project (Beneviste 1977). Technocracy shaped institutions and institutions shaped the contemporary city: in a direct and physical sense the built environment bequeathed to us by the later twentieth century embodies the values and solutions of its knowledge-providers.

The most direct and visible translation of knowledge into physical form occured within residential neighbourhoods. Mass housing, supplied by the state and designed formulaically to scientific principles of the existenzminimum, had always been a defining vision of the Modern Movement. Implemented on a vast scale around the world, the planned residential landscape proved entirely unlike any earlier typology of human settlement (Urban 2012). Thanks to the intrinsic standardisation of mass housing it displayed remarkable similarities to either side of the Iron Curtain (Monclús and Díez Medina 2016). Salient common elements were the emphasis on output, standardisation, economy and movement 
of assembly cranes, and the disregard for user preferences, tenant convenience, residential mobility and local culture (Pawley 1971; Ravetz 1995; Cupers 2011). Discontent with the depersonalisation of mass housing contributed significantly to a wider disillusion with the supposedly omniscient planner.

\section{The Second Wave}

Reaction against the institutional landscape of postwar decades explains the second surge of interest in technocracy. Armytage's Rise of the Technocrats (1965) opens with that image of Laocoön and ends with a warning of the inherently hierarchical, authoritarian tendency of rule by experts. The political ferment of the 1960s had thrown open the postwar assumption that the technical knowledge of planners would serve a benificent public interest, and that the trees of science and of life necessarily grew from the same root system. The Frankfurt school challenged that assumption through the critique of instrumental rationality by Max Horkheimer, Herbert Marcuse and then Jürgen Habermas (1970). Jean Meynaud's Technocracy (1968) traced the shift of power and accountability within the French state to autonomous agencies controlled by engineers and scientists, a processed critiqued equally from the Christian anarchist perspective of Jacques Ellul (1964) and the humanistic Marxism of Henri Lefebvre. British town planners active in urban redevelopment found themselves challenged from the grassroots by affected residents and workers, their voices amplified by activist social scientists such as Norman Dennis $(1970,1972)$ and Jon Gower Davies (1972). In a pincer movement, the critique from specific 
and local considerations was matched by generic shifts of post-modern epistemology that undermined all forms of holistic expertise and emphasizing the relational, provisional nature of human knowledge.

So the word technocracy became, as Gunnell puts it, 'Janus-faced' (1982 p382). 'Few terms in political sociology are used as loosely' (Centeno 1999 p309). On the one hand it continued to be used to describe any institutional arrangement that empowers non-elected professionals, insulating decision-making from the play of political opportunity and market speculation. To take two examples from the relevant literature, Trevor Goldsmith (2011) shows how the Spanish Ley del Suelo of 1956, devised as a technocratic measure under Franco, became a corner-stone of municipal policy after the restoration of democracy. Miguel Angel Centeno (1993) analysing the phenomenon of technocracy among national policy elites of Pacific Rim states such as Mexico, South Korea, Taiwan and Singapore, notes how their acceptance is contingent on an ability to deliver sustained economic growth: should that falter so would the model.

The alternative meaning of technology is pejorative. Measured against the implicit norm of democracy, it implied - like kleptocracy or theocracy - a capture of power from the demos by an unaccountable elite. Jürgen Habermas's Lure of Technocracy (2016) faults Jean Monnet, Jacques Delors and their successors not because they erected the European project on a foundation of independent, functional expertise but because they failed to develop the matching superstructure of discursive politics that would give it legitimacy. As Larochelle notes (1993 p124), this concept of technocracy as 'a deviationist syndrome' came to 
dominate the literature. Once seen as a solution, the t-word had become an imbalance requiring correction. This was the critique that played into neo-conservatism's emerging attack on public sector expertise. It fed the sea-serpents swimming below the social horizon of the Welfare State.

\section{Technocracy and Neo-Liberalism}

The accessions of Margaret Thatcher in 1979 and Ronald Reagan in 1981 marked a turning-point. Both brought advisers from the secretive realm of neo-conservative think-tanks and turned their libertarian conjectures into hard political reality. The shift was sudden and profound. As an illustrative example, consider the White Paper Streamlining the Cities published by the government of Mrs Thatcher four months after her second election victory in 1983. It posed an audacious challenge to the conventional wisdom that the governance of the modern metropolis required metropolitan-scale institutions (White, 1975; Barlow 1991). In the libertarian perspective of James Buchanan's Public Choice theory, all big-city governments were Gargantuas imposing redistributive levies to subsidize their inherent inefficiency. The alternative proposed by Vincent Ostrom, Charles Tiebout and Robert Warren in a classic paper for American Political Science Review (1961) was for big cities to be governed polycentrically, by multiple municipalities contracting for shared services as their voters saw fit, and competing amongst themselves to attract population and investment (Bish 1971). Streamlining and the resulting Local Government Act of 1986 translated the New Right's theoretical blueprint into an operational design for England's seven largest conurbations. Many aspects of this rash, 
Nietzschean act (O'Leary 1987) proved unworkable and have been reversed over the past three decades, but the basic shift towards reliance on quasi-market mechanisms was prophetic and has proved irreversible.

It is worth remembering that the New Right were technocratic in both senses of the word. On the one hand they embodied the presence of social scientists at the seat of power: Martin Bulmer writes of the influence of Professors Brian Griffiths, Alan Walters and Milton Friedmann, 'paradoxically the free-market policies pursued by the Thatcher government provide impressive evidence of the impact which social science ideas may have upon practical affairs' (1988 p39). After all, as Centeno notes (1993 p 311) the market logic of non-zero sum games yielding equilibria through the invisible hand of competition might well appeal to the technocrat who aspires to abolish conflict through optimization and efficiency. On the other hand libertarians drew upon the prevailing concept of technocracy as an elite conspiracy. The antitechnocratic consensus, as DuPuis and Gareau (2008) call it, undermined the analytic base of general welfare economics and opened the door to methodological individualism, political particularism and a free play of sectional interest.

\section{Conclusion}

Narratives of the history of ideas are rarely linear. Concepts twist and reverse and their meanings are shifted through a process of historical dialectic. In the century since its first appearance, 'technocracy' started as a political movement to empower public expertise in the tradition of Saint-Simon, Auguste Comte and Thorstein Veblen; dissolved into the 
larger advocacy of planning within the Modernist project; reemerged as a critique of synoptic knowledge and advocacy of discursive pluralism; and has been overtaken a second time by the sea-serpents of NeoLiberalism as they twine round the institutional structures of the mid twentieth century, privatising many, eradicating others, or penetrating their value systems to align with global corporate agendas.

So the final message of this chapter is, beware the delegitimisation of technical expertise. We can see it in the ongoing transformation of the everyday infrastructure of local public services - schools, parks, housing, buses, social care, planning, the public realm, and the local state system that sustained it. The institutional capacity of local governments, built over a time-span of a century and a half, included expertise in strength and depth. Technocracy had its pathologies but was also an essential component of an effective public service.

Arguably the heart of this conflict lies in the arena of environmental management where the scientific advice of climatologists and environmental economists is pitted against the business interests of global petrochemical corporations for stakes of no less than planetary survival. The periodic reports of the Intergovernmental Panel on Climate Change represent a massive technocratic application of scientific knowledge to the central contemporary question of human welfare. The 1987 intergovernmental initiative to ban ozone-depleting gases (chlorofluorocarbons and methy bromide) under the Montreal Protocol has often been held up as a successful precedent for greenhouse gas limitation under the Paris Treaty. But implementation of the methyl bromide phaseout has been slowed by the liberal allowance of 
exemptions, justified not through a general calculus of costs and benefits but through 'market disruption' impact on particular classes of users. In their important study of neoliberal knowledge, the decline of technocracy and the weakening of the Montreal Protocol, Melanie DuPuis and Brian Gareau provide a timely take-home message to end our historical chapter (2008 p1212):-

'The legitimization of a particularist knowledge regime opens up policy making to domination by private interests playing the stakeholder game. Stakeholder input and particularist knowledges are important to democratic decision making. However, technical expertise, despite all its weaknesses, is a form of knowledge that remains necessary to the protection of the environment and public health'.

... and, we can add, to cities that are equitable and liveable, and to a sustainable future for planet Earth. 


\section{References}

Akin W.E. (1977) Technocracy and the American Dream: the Technocratic Movement 1900-1941 Berkeley: University of California Press

Armytage, W. H. G. (1965) The Rise of the Technocrats London: Routledge \& Kegan Paul

Barlow, Max (1991) Metropolitan Government London: Routledge

Benveniste, Guy (1972) The Politics of Expertise Berkeley: Glendessary Press

Bish Robert L (1971) The Public Economy of Metropolitan Areas Chicago: Markham Publishing Co

Bulmer, Martin (1988) 'Social Science Expertise and ExecutiveBureaucratic Politics in Britain' Governance: an International Journal of Policy and Administration 1, 1, 26-49

Centeno, Miguel Angel (1993) 'The New Leviathan - the dynamics and limits of Technocracy' Theory \& Society, 22.3, 307-335

Creese, Walter (2003) TVA's Public Planning: the Vision, the Reality Knoxville: University of Tennessee Press

Crewe, Tom (2016) 'The Strange Death of Municipal England' London Review of Books, 3924 6-10 
Cupers, Kenny (2011) 'The expertise of participation: mass housing and urban planning in post-war France' Planning Perspectives 26, 1, 29-53

Davies, Jon Gower (1972) The Evangelistic Bureaucrat : a study of a planning exercise in Newcastle upon Tyne London: Tavistock

Dennis, Norman (1970) People \& Planning: the Sociology of Housing in Sunderland London: Faber \& Faber

Dennis, Norman (1972) Public Participation and Planners' Blight London: Faber \& Faber

Doob, Leonard W. (1940) The Plans of Men New Haven: Yale University Press

DuPuis, Melanie and Gareau, Brian (2008) 'NeoLiberal Knowledge: the Decline of Technocracy and the Weakening of the Montreal Protocol' Social Science Quarterly, 89, 5, 1212-1230

Ellul, Jacques (1964) The Technological Society New York: Vintage Books Fischer, Frank (1990) Technocracy and the Politics of Expertise Newbury Park: Sage Publications

Goldsmith, Trevor (2011) 'From Falangism to Technocracy: The Legislation and the Reality of Spanish Urbanism in Barcelona, 1939-1976' Journal of Urban History, May 2011, Vol.37(3), p.331 
Gunnell, John (1982) 'The Technocratic Image and the Theory of Technocracy' Technocracy and Culture 23, 392-416

Gutkind E. A. (1943) Creative Demobilization Volume I: Principles of National Planning London: Kegan Paul, Trench, Trubner \& Co

Gutkind E. A. ed (1943) Creative Demobilization Volume II: Case Studies in National Planning London: Kegan Paul, Trench, Trubner \& Co

Habermas, Jürgen (2015) The Lure of Technocracy Cambridge: Polity Press

Hayek, Friedrich (1944) The Road to Serfdom London: Routledge Kegan Paul

Huxley, Julian (1943) TVA - Adventure in Planning London: Architectural Press

Larochelle, Gilbert (1993) 'Élements pour une Compréhension Subversive de la Technocracie' Cahiers Internationaux de Sociologie [N.S.] 94, 121-143

MacLean, Nancy (2017) Democracy in Chains: the Deep History of the Radical Right's Stealth Plan for America New York: Viking

Mannheim, Karl (1951) Freedom Power and Democratic Planning London: Routledge \& Kegan Paul

Meynaud, Jean (1968) Technocracy (trans. Paul Barnes) London: Faber \& Faber 
Monclús, Javier and Díez Medina, Carmen (2016) 'Modernist Housing Estates in Western and Eastern Socialist European Cities - How Different ?' Planning Perspectives, 31, 1, 1-30

O'Leary, Brendan (1987) 'Why was the GLC abolished ?' International Journal of Urban Research 11, 2, 193-216

Ostrom, Vincent, Tiebout, Charles and Warren Robert (1961) 'The Organization of Government in Metropolitan Areas - a Theoretical Inquiry' American Political Science Review 55, 4 607-30

Pawley, Martin (1971) Architecture versus Housing, London: Studio Vista Phillips-Fein, Kim (2009) Invisible Hands: the Making of the Conservative Movement from the New Deal to Reagan New York: W.W. Norton \& Co Plowden, William (1968) 'Expert Opinion' New Society October 3rd p.498 Popper, Karl (1957) The Poverty of Historicism London : Routledge Kegan Paul

Ravetz, Alison (1995) the Place of Home: English Domestic Environmenys 1914-2000 London : E\&F Spon

Siegel \& Strain Architects (2011) Smyth-Fernwald Property, Historic Structures Report [Report to the University of California] Online resource, accessed 23rd August 2017: 
http://realestate.berkeley.edu/sites/default/files/hsr_smythfernwald_m arch2011.pdf

Smyth, William Henry (1926) Concerning Irascible Strong et al, New York: Alfred A. Knopf

Urban, Florian (2012) Tower and Slab: Histories of Global Mass Housing London: Routledge

Valade, Bernard (2008) "Variations sur l'Urbanisme de l'État en Région Parisienne 1919-1969' L'Année Sociologique, 58, 1, 121-142

White, Anthony (1975) Reforming Metropolitan Governments New York: Garland Publishing Co. 


\section{Figure captions and credits}

Fig.1 Laocoön and his sons attacked by sea-serpents

Vatican Museum, Catalogue No. 1059

Sourced by kind permission from :

http://www.museivaticani.va/content/museivaticani/en/collezioni/mus

ei/museo-pio-clementino/Cortile-Ottagono/laocoonte.html

Fig.2 'Technocracy' frequency graph

Google Ngram from the corpus of books in English, 1920-2015, with a smoothing of 3.

Source: https://books.google.com/ngrams

Fig.3 Concerning Irascible Strong and Trixie Cunning . . and Their Descendants

Smyth (1926) title-page, from Siegel \& Strain (2011 p.29)

Source: Bancroft Library, Berkeley, California, by kind permission and with thanks to Henry Seigel

Fig.4 Arbor Scientiae Arbor Vitae

Title-page symbol of the International Library of Sociology and Social Reconstruction published by Routledge Kegan Paul

Source: author's collection 
Bio

Michael Hebbert, Professor Emeritus of the University of Manchester and University College London, is attached to the Bartlett School of Planning at $\mathrm{UCL}$ 
